that the preparations for the service were approaching completion, and that Capt. Cyril Diver had been appointed to take charge of it and had taken up his duties that day. The London office of the service is at Thorney House, Smith Square, S.W.1. Capt. Diver brings to his new post extensive administrative experience as clerk of the Financial Committee of the House of Commons, and in addition has long been keenly interested in natural history, and in particular the study of ecology. While on active service in the First World War he made a study of snails in the trenches. He has been an active member of the British Ecological Society, of which he has been president. He served on the Nature Reserves Investigation Committee and assisted in drafting its report, and also on the Wild Life Conservation Special Committee, which in its report recommended the formation of a Biol ogical Service in Great Britain.

Social Studies at Sheffield: Miss Ellinor I. Black

THE University of Sheffield has recently decided to create a new School of Social Studies, which will provide a postgraduate course leading to a diploma in social studies, and other courses leading to lower qualifications. The School will be governed by a board, on which the Science as well as the Arts Faculty will be represented. As a first step to establishing the school, the University has appointed Miss Ellinor I. Black as its director. Miss Black has been associated with the Social Science Department of the University of Liverpool, which she joined in 1924 at the most critical period of its development. Since 1941 she has been a senior lecturer, and for five years during the period of the War she acted as head of the Department. In addition to the reputation she has established in Great Britain, she has also created for herself a somewhat unique position in the international field; she has since 1936 been closely connected with the Social Welfare Committee of the League of Nations, and the International Committee of Schools of Social Work. In recent months she has renewed her personal contacts with schools of social work in the United States and in Germany. Miss Black is particularly interested in the welfare of the aged. She was a member of the Old Age Survey Committee of the Nuffield Foundation, and she has carried out detailed investigations of the problem in the Merseyside area. Miss Black has made a very deep impression on the education of the professional social worker in Great Britain; as a teacher she has been able to win both the intellectual and the more personal loyalties of her students, as so many that have passed through the Liverpool School can testify. Sheffield will gain in her one who will devote herself wholeheartedly to the creation of the new institution, which will thus possess a very special human quality.

\section{Cooled-Anode Radio Valves}

THE new chairman of the Radio Section of the Institution of Electrical Engineers, Mr. F. Smith, delivered his inaugural address on October 13, under the title of "The Development and Design of Cooled. Anode Valves". 'The term 'cooled-anode valve' is applied to all valves having anodes which form part of the envelope, without discrimination between the different methods of cooling. Probably the earliest valve using air-cooling was the Catkin receiving valve produced in 1933, as a miniature of the then existing large water-cooled transmitting valve. When similar methods of construction were used for valves of about 60-watts dissipation, it was necessary to add a radiator with fins to the anode. The approach of the Second World War, with its demands for special short-wave transmitting valves for pulse operation, led to the development of several series of valves with external anodes cooled by a forced air draught.

Mr. Smith's address was a survey of the development during the past ten years of the various types of cooled-anode transmitting valves. The special problems associated with the use of thoriatedtungsten filaments and oxide-coated cathodes, with the glass-to-metal joints, and the construction and cooling of the electrode seals were described. As the operating-frequency was increased, special design problems were encountered in dealing with the reduced dimensions and electrode spacings. At the highest frequencies, the valve has necessarily to be regarded as an integral part of the oscillatory circuit, and this may take the form of a coaxial transmission line or resonant-cavity in some cases. Recent developments, over the whole range of valves, have continued to be chiefly in the direction of obtaining more power at higher frequencies, and of maintaining this output over a greater band of operating frequencies. The successful development of such valves with water. cooling has been a major factor in many modern radio applications.

\section{Radio Components Exhibition in Stockholm}

A private exhibition of radio and electronic com. ponents held in Stockholm during October 18-22 was arranged by the Radio Component Manufacturers' Federation, which is a constituent association of the Radio Industry Council in Great Britain. Some thirty-seven British firms participated and showed a wide range of products, including transformers, resistors, condensers, plugs and sockets of the many different types now in use, together with chassis, cables and terminals which contribute to the assembly of modern electronic equipment. Certain classes of measuring apparatus for the testing of such equipment were also displayed.

The exhibition was opened by Mr. J. Thyne Henderson, chargé d'affaires at the British Embassy in Stockholm, and a large number of people took advantage of the invitations to attend. It was stated that many of the components and instruments had not previously been demonstrated outside Great Britain, and that it would assist British exports to Sweden to arrange this display. In conjunction with the Federation's exhibition, and at the invitation of the British Council, Dr. R. L. Smith-Rose, director of radio research in the Department of Scientific and Industrial Research, gave two lectures at the Royal Institute of Technology, Stockholm. In the first of these lectures, he described the principles of radar and the various types of radio navigational aids, while in the second he surveyed the progress made in the development of some radio and electronic techniques during the past few years.

\section{Science Teaching at the City of London School}

IN 1839 the Rev. W. Cook was appointed to the City of London School to deliver ten to twelve lectures a year on chemistry and natural philosophy, and this was considered sufficient until 1845, when the programme was increased to four lectures per week. In 1847 Thomas Hall, who was already on the staff, was appointed as lecturer, and the teaching of 
science in the School may be reckoned to commence from this date. On Hall's retirement in 1869 , he was succeeded by Henry Durham, who had joined the staff with Isaac Scarf in the previous year. These two gave yeoman service to the School and did not retire until 1910 and 1919 respectively. They taught throughout a period when science underwent revolutionary changes, and the development of science teaching in the School kept pace accordingly. In 1869 Dr. Abbott, the headmaster, introduced science throughout the curriculum, and his successor, Mr. Pollard, founded the science side in 1892 ; the jubilee of the teaching of science was marked in 1897 with the Hall Memorial Scholarship. Durham was succeeded by G. C. Donington as senior science master, but the latter died soon afterwards and was replaced by G. H. J. Adlam, who died recently. In 1927 the new science laboratories were opened by the Lord Mayor of London, and they consisted of advanced and elementary laboratories, a chemistry lecture room, a balance room and a room for the science staff; soon afterwards, in 1929, a biological laboratory was completed. A further biological laboratory and a museum were added in 1937, and in 1946 the balance room was converted to an advanced physics lecture room.

The centenary of the teaching of science fell in 1947 and was celebrated at the Great Hall of the School on the afternoon of November 6 this year. There was a large gathering of officials of the Corporation, the Schools Committee, the School staff, parents, and past and present pupils, and the chief guest was the Lord Mayor and Lady Mayoress of London. The headmaster, Mr. F. R. Dale, reminded his audience that, on inspecting some laboratories, a predecessor of his, Dr. Abbott, had once said, "You and I know that this is not education". The Lord Mayor made a short address, and was followed by Sir Harold Scott, lately director of the Bureau of Hygiene and Tropical Diseases, who was himself an old pupil of the School. Various demonstrations and exhibits had been arranged in the School laboratories.

\section{Chemistry and Chemical Technology at University College, Dublin}

Mr. Michael Tiernex, president of University College, Dublin, recently opened in the College a new laboratory for the teaching of chemical technology. Prof. T. S. Wheeler explained that this new laboratory would be known as the Nolan Laboratory in remembrance of the late Prof. T. J. Nolan, whose untimely death had prevented him putting into operation plans he had formulated for the teaching of chemical technology in the College. Mr. Tierney also opened a laboratory for final years honours chemistry, which will be known as the Ryan Laboratory, in remem. brance of the late Prof. Hugh Ryan, the first professor of chemistry in University College, Dublin.

\section{Bioluminescence}

IN connexion with Dr. V. B. Wigglesworth's article on bioluminescence in Nature of September 11 , p. 423, Mr. K. B. Williamson, c/o Manson House, 26 Portland Place, London, W.1, has recalled observations made by him while he was malaria research officer in Malaya some years ago. A dytiscid beetle which fell about three feet off the laboratory bench on to the floor of the old Malaria Bureau, Kuala Lumpur, displayed a unique type of bioluminescence. The beetle appeared to emit bright flashes of white light, three or four at a time, from its eyes.
The fluorescent type of bioluminescence is invisible even in weak light ; but these flashes were conspicuous in competition with the light from a fairly bright electric bulb on the laboratory bench. The groups of flashes were repeated several times within half an hour, when the beetle was again dropped from the same height; but never afterwards, when the dropping was repeated during the subsequent months it was kept alive. In sharp contrast to another Dytiscus, it failed to capture any mosquito larvæ or pupæ during these months, and it not improbably died of starvation; and may have been blinded by destruction of retinal pigment and damage to the cells producing it. Mr. Williamson tentatively suggests that the flashes from the beetle's eyes were caused by reversal of the normal process of vision, energy in the form of light having been emitted instead of being absorbed by retinal pigment, as the result of intermittent outwardly directed nervous impulses, due to shock.

\section{Earthquakes during July and August}

DuRING July, nineteen strong earthquakes occurred in various parts of the world, the strongest being of instrumental scale $7 t$ and occurring off the southwest coast of Peru on July 20. It had a depth of focus of $100 \mathrm{~km}$. Two earthquakes on July 16 radiating from a focus having an epicentre near the coast of Guatemala and having strengths $6 \frac{1}{4}$ and 68 were felt in Guatemala and San Salvador. The only earthquakes to do damage during the month occurred on July 20, damaging buildings on Coiba Island.

During August, twenty-four strong earthquakes occurred in various parts of the world. The strongest occurred on August 25 in the Salta Province of Argentina and attained scale $7 \frac{1}{2}$. During the month there was also rather more activity than usual along the south European seismic zone, earthquakes occurring on August 10 in the region of Alasehir in Turkey; on August 12,13 and 15 near Oporto in Portugal; on August 18 near Sivrice in Turkey, and at Apulia in south Italy; on August 21, destructive at Orda Nova in south Italy; on August 22 in Portugal and Italy; and on August 27 in the region of Skadar, Albania. On August 30 there was also a repetition of an earthquake which occurred on July 8 in a rather unusual area-near Jan Mayen Island.

Group reports have been received from the United States Coast and Geodetic Survey, the central station at Strasbourg, the Jesuit seismological central station at St. Louis, United States, and individual station reports have been received from Beograd, Cleveland (Ohio), De Bilt, Durham, Kew, Stuttgart, Toledo and Uccle.

\section{Polytetrafluoroethylene}

THE outstanding stability of fluorinated hydrocarbons has been fully exploited in the field of high polymers. The preparation and polymerization of tetrafluoroethylene was described some two years ago (Ind. Eng. Chem., 870; 1946). The polymer (P.T.F.E.) is an excellent dielectric (power factor = 0.0002 over a wide frequency-range) and it is resistant to all common solvents up to $300^{\circ} \mathrm{C}$. Molten alkali metals alone have any appreciable attack. In its strength, however, lies its greatest weakness. Form stability is retained up to $250^{\circ} \mathrm{C}$., and even at higher temperatures there is no true softening; thus moulding and fabrication present major obstacles. Pro. gress in overcoming this difficulty has, however, been made by Messrs. British Mechanical Productions, 